\title{
Research and control of the Risk of EPC Contractor Based on the Supply Chain
}

\author{
Hong Ke, Jinyan Xu \\ School of management, Tianjin University of Technology, Tianjin 300384, China
}

Keywords: Supply chain, EPC, Risk management, Contractor.

\begin{abstract}
Engineering, Procurement and Construction (EPC)/Turnkey Contract is mature in developed countries, like America and European countries .But to China, it's a relatively new thing . The wide use of EPC Contract will meet a lot of problems. In order to solve management problems of the EPC contract, the construction industry began to introduce supply chain management ideas, theories and methods. As distinguishing feature of construction industry, the construction project supply chain risks are unique. The risks will be very costly.How to control the contract risk is the most important thing to the contractor. This article starts from the correct understanding of EPC supply chain and its risk characteristics. At first, EPC supply chain are defined, a EPC supply chain management model is established, and on the basis of relevant theory of general supply chain risk and its management, combining with characteristics of general contracting EPC supply chain, the general contracting EPC supply chain risk is identified and analyzed. Then, the principles of making general contracting EPC supply chain risk assessment index system are determined. Finally, from the perspective of system management and comprehensive risk management, the comprehensive risk management framework for general contracting EPC supply chain is built, at the same time its corresponding support conditions are analyzed in order to achieve effectiveness, integrity and value of risk management, and to improve the risk management.
\end{abstract}

\section{Introduction}

EPC contract model in China is still relatively new, currently only been used in the chemical, electrical and other small industries, its wide application faces many problems. The general contractor, the risk management bear the brunt. Under the EPC contract model, the general contractor in improved profits, contracts powers strengthened, while exposure also increases. From the contractor's point of view, undertake EPC contracting international engineering projects, both opportunities and risks, if the contractor can use reasonable technical means to control and manage risk, will be able to win at the same time profits, continue to develop and grow their own[1]. Risk Management of EPC Project is still in its infancy, so the research on risk management contractor under the EPC contract conditions, and will help Chinese construction enterprises in the international market and increase their international business development business development level.

\section{EPC Contractor Risk Analysis}

Based on the principle of easy control, the risk of EPC projects in accordance with the classification of risk factors can be drawn from a list of EPC project risk, as shown in Table 1. Some of the major risks just EPC projects listed here have in common[2]. Special types of projects may produce its special risks, these elements are discussed in this article do.

${ }^{[1]}$ Tian wei. FIDIC Conditions of Contract practical skills [M] Beijing: China Building Industry Press, 2002 
Table.1 List of contractor's risks in EPC model

\begin{tabular}{|c|c|c|}
\hline NO. & Risk Category & Detailed risk \\
\hline 1 & Political & $\begin{array}{l}\text { war / revolution / social unrest, government instability , discontinuity of } \\
\text { government policy, bureaucracy }\end{array}$ \\
\hline 2 & Social & $\begin{array}{l}\text { Social security is low, the diseases and medical facilities, the lack of a legal } \\
\text { system ,different cultural practices, lack of commercial facilities }\end{array}$ \\
\hline 3 & Natural Environment & $\begin{array}{l}\text { unforeseen geological conditions, bad weather affected, floods, earthquakes and } \\
\text { other disasters }\end{array}$ \\
\hline 4 & Economic & $\begin{array}{l}\text { interest rate fluctuations, inflation, tax rates rise, the owners shortage of funds / } \\
\text { payment is not in place, supervision delays and deductions, bond forfeiture }\end{array}$ \\
\hline 5 & Technical & $\begin{array}{l}\text { design risk, poor quality design level, whether the design and post-procurement, } \\
\text { with the construction, design or description is not specific enough, inaccurate } \\
\text { difference norms and standards, the application of new technologies, survey data, } \\
\text { materials procurement and quality defects }\end{array}$ \\
\hline & & $\begin{array}{l}\text { Risk, subcontractors technical level defects, transport risks, the owners request a } \\
\text { change, difficult construction }\end{array}$ \\
\hline
\end{tabular}

\section{EPC Contractor Response To The Risk And The Contract Price In A Contract Entered Into Stage}

Contractor response to the risk and the contract price in the bidding stage. EPC general contractor risk management should start early, the sooner the better. Low upfront investment, the latter can better control of project risks. Experienced contractor before deciding to bid on the items on the owners want a long-term contract tracking, collect a lot of basic information, so that within a limited period may make a bid as a full analysis of project risks. At the tender stage, EPC contractor can risk response from the following aspects:

i) Carefully read the contract documents.

ii) Depth investigation works in the political and economic situation.

iii) In a bid to determine the special investigation group relevant laws or regulations personnel, the law of the State where the conduct in-depth research project, if necessary, to consult a local attorney or agent.

iv) For international projects, where project to investigate the country religion, customs, such as local Christians to engage in religious ceremonies prescribed daily events, religious festivals which sustained length of time.

Contractor response to the risk and the contract price in the contract negotiation stage. Contract negotiation and signing phase is crucial for the contractor, EPC contract provisions will be in the future to resolve their dispute, provided the claim is based on the highest standards. Therefore, in the negotiation and signing of the contract stage, the contractor should be possible to avoid or reduce the risk, the risk of future losses that may occur will be reduced to a minimum. Mainly take the risk of EPC avoidance, risk transfer and other measures response to the risk:

i) Carefully review the contract documents

ii) Be reasonable contract terms:payment terms, additional terms of preservation, the risk of additional contract terms, participate in the forex insurance

\section{EPC Contractor Response To The Risk And The Contract Price In Contract Performance Stage}

Contractor response to the risk and the contract price in the design stage. According to a phased plan approval fast and high quality design and drawings.

Statistics show that impact of of foreign investment in the design phase is about $90 \%$, while only $10 \%$ of the construction phase. Obviously, the design phase is the key to control of investment, in order to effectively control project cost, we must attach great importance to the design phase management control, schedule control, and improve engineering efficiency plays a key role[3].

Design stage investment control should be noted that: 
i) Preliminary design should pay attention to the program selected in accordance with the investment phase of the feasibility study to estimate the likelihood of further implementation of the approved investment.

ii) Enhance process control engineering survey and design.

iii) To limit the design throughout the various stages of design, implementation is the professional realization of the total quota limit guarantee.

Contractor response to the risk and the contract price in the procurement stage. Purchasing department procurement schedule will be available by the schedule of construction materials submitted to the department, the arrival time and the number of clear materials, and time requirements into the library; construction sector should be based on supply plan, good pick preparations; after the material delivered to site, procurement staff to timely construction and warehouse management departments of the handover.

EPC contract procurement including procurement of engineering equipment procurement and materials procurement, and special technical services, etc.. Procurement aspects of investment control should note the following:

i) Establish a bidding system, the introduction of market competition mechanism to reduce procurement costs.

ii) Procurement, contract conditions and technical standards should be clear and tight, avoid vague and contradictory terms appear.

iii) Try to take the lump sum contract model, reducing the difficulty of implementing the contract, to avoid excessive change management.

iv) Related to the design department to participate in the procurement standards, in particular, to the subject matter of strict requirements, to meet the requirements of the total contract, and nothing more, does not exceed the standard procurement or "gold-plated" procurement.

Contractor response to the risk and the contract price in the construction stage. Risk for the construction phase, EPC contractor can take the risk avoidance, risk transfer, risk mitigation, risk retention and other measures response to the risk. The EPC contractor may risk responses are summarized as follows:

i) Reduce the funds advanced by the contractor and equipment.

ii) The Contractor main response is: rational use of subcontractors, strengthen control.

iii) HSE factors for dynamic management.

iv) To strengthen cost control, quality and progress.

Construction stage contractor contract price.The construction phase is an important part of the construction investment control, from the selection of construction subcontractors begin until the completion of the project to control the whole process. Therefore, the construction subcontractors should also adopt a more mature bidding system. In the sub-contract, EPC general contractor should clearly bear the risk of major projects, if the main risk passed to the construction subcontractors, subcontractors may face a financial crisis, or a lack of ability to cooperate if the subcontractor, the general contractor greater losses. Therefore, when selecting subcontractors, should be integrated capabilities and subcontractor bidding.

During the construction phase of the construction project, the design has been finalized, only through the optimization of construction techniques and organizations including the site design changes and visa control, due to lower construction costs, the cost of adjustment to a lesser extent. At this stage investment control work more complicated, in addition to the normal owners and subcontractors examine and value the work and statistical reports, change control claims costs is a key investment work.

\section{Conclusions}

In this paper, on the basis of other's research results, the main work and conclusions:

i) The EPC project general contracting and risk management contract entered into a contract to perform in two stages. Classify and analyze the risk of the contractor and the impact on the various 
stages of the contract price, the contractor proposed risk response measures and the various stages of the contract price control policy

ii) Entering into the contract stage, the contractor can focus on market research and site visits, for a reasonable contract terms, segmented pay the contract price is reasonable audit and other ways to deal with risk. The contract is divided into stages of bid price control charter, contract negotiations, the contractor proposed the corresponding contract price control policy.

iii) The stage of performance of the contract, the contractor may deal with the design, construction organization and management, procurement management and other risks. Contractor may, at the design stage by careful and detailed design, do start to prepare, timely advice or actively communicate with the owners, according to a phased plan approval fast and high quality design and drawings, send skilled and understand contracts while the language ability of people management contracts and other ways to deal with the risk .

In short, EPC contracts conform to the way the international situation and the development of the current situation, with a wide range of applications in practice. With the academic theory and business continued tireless exploration efforts in the EPC project risk management practices, EPC project risk management in the depth and breadth will have made great progress.

\section{References}

[1]W. Tian. FIDIC Conditions of Contract practical skills. Beijing: China Building Industry Press, 2002

[2] S.B. Zhang. A new international project contracting-EPC contract model contract. China Harbour Engineering, 1999

[3] R.H Wang.. On the international hydropower project construction cost control EPC Contract Project. Conservancy and hydropower project cost .2008, (4) :27-29. 